\title{
Peritoneal Lymph Node
}

National Cancer Institute

\section{Source}

National Cancer Institute. Peritoneal Lymph Node. NCI Thesaurus. Code C77644.

A lymph node located in the peritoneum. 